\title{
Determining oil and dispersant exposure in sea turtles from the northern Gulf of Mexico resulting from the Deepwater Horizon oil spill
}

\author{
Gina M. Ylitalo ${ }^{1, *}$, Tracy K. Collier ${ }^{2}$, Bernadita F. Anulacion ${ }^{1}$, Kristy Juaire ${ }^{3}$, \\ Richard H. Boyer ${ }^{1}$, Denis A. M. da Silva ${ }^{1}$, Jennifer L. Keene ${ }^{4}$, Brian A. Stacy ${ }^{4}$ \\ ${ }^{1}$ Environmental and Fisheries Sciences Division, Northwest Fisheries Science Center, National Marine Fisheries Service, \\ National Oceanic and Atmospheric Administration, 2725 Montlake Boulevard East, Seattle, WA 98112, USA \\ ${ }^{2}$ Joint Office for Science Support, University Corporation for Atmospheric Research, 3300 Mitchell Lane, Boulder, CO 80301, USA \\ ${ }^{3}$ Marine Safety Laboratory, US Coast Guard, 1 Chelsea Street, New London, CT 06320, USA \\ ${ }^{4}$ Office of Protected Resources, National Marine Fisheries Service, National Oceanic and Atmospheric Administration, \\ 2187 Mowry Rd, Gainesville, FL 32611, USA
}

\begin{abstract}
Documentation of exposure of threatened and endangered sea turtles to petroleum and dispersant released into the northern Gulf of Mexico (GoM) during the Deepwater Horizon (DWH) oil spill was a critical component of the Natural Resource Damage Assessment (NRDA) process. Substances collected from the skin of oiled and suspected oiled turtles were analyzed for petroleum hydrocarbons to determine oiling status and oil sources. Tissue, gastroenteric and bile samples from a subset of visibly oiled and unoiled turtles that died during the spill in 2010 and in 2011 were analyzed for evidence of internal exposure and absorption of polycyclic aromatic hydrocarbons (PAHs) and the dispersant component dioctyl sodium sulfosuccinate (DOSS). The volume of external oil collected from sea turtles was sufficient to confirm the presence of petroleum on $61 \%$ of turtles, and oil from the DWH spill was identified as the source in $97 \%$ of those turtles in which conclusive comparison was possible. Visibly oiled turtles had higher concentrations of tissue PAH or biliary fluorescent PAH metabolites compared to those determined in unoiled animals. Findings in most of the unoiled turtles were suggestive of low-level PAH exposure from various sources that may represent background values for sea turtles from the northern GoM. DOSS levels were below the limit of quantitation in all samples analyzed except in an esophagus sample of a heavily oiled sea turtle. Overall, the results for petroleum or petroleum-derived compounds of both external and internal samples of sea turtles supported visual observations of oiling.
\end{abstract}

KEY WORDS: Deepwater Horizon oil spill $\cdot$ Sea turtles $\cdot$ Oil exposure $\cdot$ Dispersant $\cdot$ Oil spills

\section{INTRODUCTION}

After the collapse of the Deepwater Horizon (DWH) drilling platform and the subsequent failure of the Macondo 252 (MC252) wellhead on 22 April 2010, an estimated 3.19 million barrels of Louisiana crude oil were released into the waters of the northern Gulf of Mexico (GoM) approximately $1500 \mathrm{~m}$ below the surface (DWH NRDA Trustees 2016). The DWH oil spill

\footnotetext{
*Corresponding author: gina.ylitalo@noaa.gov
}

was the largest marine oil spill in US history. Extensive oil spill response activities occurred in the northern GoM region, including skimming and booming operations in nearshore areas, skimming, booming and burning of oil offshore, and application of approximately 1.84 million gallons $\left(7.0 \times 10^{6} \mathrm{l}\right)$ of dispersant to offshore surface waters and at depth near the MC252 wellhead. The marine waters of the northern GoM support a wide range of biota and were contami-

(C) The authors and (outside the USA) the US Government 2017. Open Access under Creative Commons by Attribution Licence. Use, distribution and reproduction are unrestricted. Authors and original publication must be credited. 
nated by crude oil and dispersants, and potentially impacted by oil spill response activities. Thus, there is great concern about the effects of the oil spill and the associated response activities on wildlife in the region.

The Natural Resource Damage Assessment (NRDA) process is the legal framework in the USA by which injuries from oil spills are evaluated and measures needed to restore those injuries are identified. An important component of this process is clear demonstration of exposure of natural resources to the spill, which supports causal linkages to subsequent negative effects that are then considered during the injury determination and restoration phases. Five species of sea turtle are found within the GoM and are federally listed under the US Endangered Species Act. The DWH oil spill overlapped with important sea turtle habitats and multiple life stages, thus sea turtles were one of the major taxa included in the DWH NRDA (DWH NRDA Trustees 2016, Section 4.8). Chemical analysis of samples collected from sea turtles during and following the oil spill was an important part of the damage assessment process and demonstration of exposure to DWH oil.

Crude oil contains thousands of chemical compounds, with the polycyclic aromatic hydrocarbons (PAHs) being some of the most toxic components. Concerns have been raised over the effects of exposure to PAHs on marine organisms because of the worldwide use of fossil fuels (Geraci \& St. Aubin 1990, Peterson et al. 2003) and the occurrence of oil spills in areas that support populations of marine life. Marine organisms can be exposed to PAHs by various routes (e.g. dermal absorption, inhalation, consumption of contaminated prey and sediment) and rapidly take up those present in the environment (Meador et al. 1995). However, the persistence of these compounds in tissues and body fluids of exposed marine organisms varies, depending upon the rates of uptake, metabolism and elimination (Krahn \& Stein 1998). Vertebrates, such as fish and marine mammals, quickly metabolize PAHs into more polar forms that are then excreted into urine or secreted into the bile for rapid elimination via the gastroenteric tract (Roubal et al. 1977, Krahn et al. 1992, Varanasi et al. 1993).

Sea turtles have diverse life stages, use many habitat types and were at risk of oil exposure at all life stages following the DWH oil spill. These included incubating eggs, post-hatchlings, juveniles, subadults and adults, and nesting females, with the oiling of nesting beaches, nearshore and oceanic habitats potentially affecting all of these life stages
(Milton et al. 2003). The routes of exposure to oil in sea turtles include dermal contact (skin), inhalation of volatiles, direct oil ingestion, consumption of contaminated prey and sediment, and oil fouling of sense organs, as well as oiling of eggs on nesting beaches (Milton et al. 2003). Very limited data are available on $\mathrm{PAH}$ exposure in sea turtles as compared to other taxa (Alam \& Brim 2000, Camacho et al. 2012, 2013, 2014). Physical oiling or oil ingestion by sea turtles has been documented, but tissue levels of petroleum-related compounds were not reported in most cases (Gramentz 1988, Bugoni et al. 2001, Orós et al. 2005, reviewed in Yender \& Mearns 2003). Hall et al. (1983) reported concentrations of petroleum hydrocarbons in tissues of sea turtles exposed to oil after the Ixtoc spill in the Bay of Campeche, Mexico, in 1979. In freshwater turtles, studies have focused on PAH concentrations in eggs and subcutaneous fat (Bell et al. 2006, Holliday et al. 2008, Rowe et al. 2009) or blood (Drabeck et al. 2014, Meyer et al. 2016) of turtles from known contaminated habitats. In general, information is lacking on baseline exposure, uptake and tissue distribution of parent and alkylated PAH homologs for juvenile and adult turtles. Information is also very minimal on the effects of oil exposure in sea turtles, although much is known about its toxic effects in other vertebrate species. A summary of what is known about oil toxicity to sea turtles, and estimation of the impacts of oil exposure to sea turtles following the DWH oil spill, is provided in Mitchelmore et al. (2017, this Theme Section).

In the present study, hundreds of samples collected from the skin of sea turtles reported as oiled based on field observations during and following the DWH spill were analyzed for hydrocarbons to determine petroleum exposure and potential petroleum source (e.g. MC252 oil). In addition, postmortem samples collected from oiled and non-visibly oiled turtles that were found dead or died within the northern GoM during 2010 and 2011 were analyzed for PAHs and PAH metabolites, as well as the dispersant component dioctyl sodium sulfosuccinate (DOSS), in order to investigate internal exposure and absorption of these potentially toxic compounds.

\section{MATERIALS AND METHODS}

\section{Sea turtle sample collection and inclusion in analysis}

Live and dead green (Chelonia mydas), hawksbill (Eretmochelys imbricata), Kemp's ridley (Lepido- 
chelys kempii) and loggerhead (Caretta caretta) sea turtles were collected offshore in the northern GoM during surveys of oiled habitat during the DWH spill; on and nearshore in Alabama, Florida, Louisiana, Mississippi and Texas by stranding responders; and opportunistically during other activities. All sample collection, handling and analyses were conducted under evidentiary procedures followed during the DWH spill. In this study, 2 general types of sample were analyzed: material collected from external surfaces of live and dead sea turtles, and postmortem samples collected from sea turtles that were found dead or that later died.

The oiling status of sea turtles based on visual examination was categorized as follows: no oil visible; minimally oiled, where oil was either limited to one region of the body or coverage was very light (thin smear or staining only); lightly oiled, where a thin layer of oil lightly covered multiple parts of the body and thicker aggregated oil, if present, was focally distributed, moderately oiled, where heavier layers of oil covered multiple areas of the body, often accompanied by generalized brown staining; and heavily oiled, where aggregates of thick, tenacious oil diffusely covered the body. If insufficient information was available on the quantity of oil present, degree of oiling was classified as unknown (Stacy 2012). Oil, or any substance suspected to be oil, was collected using cotton gauze or wooden tongue depressors, which were wrapped in aluminum foil, placed into a plastic bag and frozen at -80 or $-4^{\circ} \mathrm{C}$ until shipped on dry ice to the US Coast Guard Marine Safety Laboratory for analysis. Most of the oiled turtles sampled in this manner were surface-pelagic juvenile sea turtles rescued alive from oiled habitat in offshore areas during the spill (Stacy 2012). Analyses of postmortem samples included 13 visibly oiled sea turtles found during the DWH spill that were confirmed to be oiled with DWH oil based on chemical analysis of an external sample.

In addition, samples of organs and gastrointestinal contents from 66 visibly unoiled sea turtles collected in 2010 and 2011 were analyzed for potential cryptic exposure that was not associated with apparent external oiling. These cases were from different areas of the northern GoM and had a variety of postmortem findings, including known and undetermined causes of death. Those with a known location and circumstances of death, which are often lacking in stranded animals, were specifically included.

At the time of necropsy, 35 carcasses were in good postmortem condition, 40 were moderately decom- posed and 4 were severely decomposed. Thirty turtles were refrigerated and necropsied within $4 \mathrm{~d}$ of death $($ mean $=1.87 \mathrm{~d}$, range $=0$ to $4 \mathrm{~d})$, while 49 turtles were frozen prior to necropsy (mean $=104.3 \mathrm{~d}$, range $=8$ to $247 \mathrm{~d}$ ). Carcasses were carefully inspected for oil, including examination of the mouth and digestive tract. Samples of liver, skeletal muscle, lung, esophagus (visibly oiled turtles only), bile and gastroenteric contents (i.e. enteric, colon content, gastric content, feces) were collected during necropsy into certified glass containers or aluminum foil using alcohol-rinsed instruments and glass syringes. The esophageal and enteric samples analyzed in this study contained the contents of each organ, as well as portions of the lining (mucosa) and muscular wall. Esophageal samples, which consisted almost entirely of oil, were the only samples analyzed from 3 of the severely decomposed turtles and were analyzed specifically for compositional comparisons with DWH reference oil samples and for detection of DOSS, as described below.

All samples were preserved at $-80^{\circ} \mathrm{C}$ until shipped on dry ice to the Northwest Fisheries Science Center (NWFSC) in Seattle, WA, where tissues and gastroenteric samples were stored at -80 or $-20^{\circ} \mathrm{C}$ (bile only) until analysis. Bile rapidly degrades, which interferes with instrumentation; therefore bile samples for analyses were selected from sea turtles that were in good postmortem condition and had been refrigerated - not frozen - after death and necropsied within $96 \mathrm{~h}$.

\section{Chemical analyses}

Analysis of external samples

External samples were analyzed for normal and branched-chain aliphatic hydrocarbons, PAHs and petroleum biomarkers by gas chromatography equipped with flame ionization detection (GC-FID) and gas chromatography-mass spectrometry (GCMS) (see description in Section 1.0 in the Supplement at www.int-res.com/articles/suppl/n033p009_ supp.pdf).

PAH analyses of gastroenteric and tissue samples

Tissue and gastroenteric content samples were extracted and analyzed for PAHs using the GC-MS method of Sloan et al. (2014). See Section 2.0 in the Supplement for details. 


\section{Biliary PAH metabolite analyses}

Sea turtle bile samples $(n=25)$ were analyzed for fluorescence $\mathrm{PAH}$ metabolites using high-performance liquid chromatography with fluorescence detection (HPLC-F) (Krahn et al. 1992). Biliary protein content was determined as described in da Silva et al. (2006). See Section 3.0a in the Supplement for details.

Bile samples from 20 turtles were also analyzed for individual hydroxylated PAH metabolites (OHPAHs) using a modified liquid chromatography-tandem mass spectrometry (LC-MS/MS) method described by Xu et al. (2004). See Section 3.0b in the Supplement for description.

\section{DOSS analysis}

Analyses of sea turtle tissues and bile for the dispersant component DOSS were conducted using a QuEChERS (i.e. quick, easy, cheap, effective, rugged and safe) sample extraction procedure (Anastassiades et al. 2003, Ramalhosa et al. 2009) followed by LC-MS/MS analysis (Benner et al. 2010, Flurer et al. 2010) (description of method in Section 4.0 in the Supplement).

\section{Statistical analysis}

If a concentration of an individual $\mathrm{PAH}$ was below the lower limit of quantitation (LOQ) in a sample, a value of zero was used prior to calculating sums and subsequent statistical analyses. Concentrations of PAHs were $\log _{10}$-transformed and the percent lipid values were arcsine transformed to increase the homogeneity of variances. ANOVA and the Tukey-
Kramer HSD test were used to determine if mean concentrations of sum low molecular weight aromatic hydrocarbons (sum LMWAHs), sum high molecular weight aromatic hydrocarbons (sum HMWAHs) and sum PAHs (see Section 2.0 in the Supplement for description of sum LMWAHs, sum HMWAHs and sum PAHs calculations), as well as biliary fluorescent PAH metabolites, differed between visibly oiled and non-visibly oiled turtles. The relationships between percent lipid and PAH concentrations of tissues were assessed by simple correlation analyses (Zar 1999). All statistical analyses were completed using JMP statistical software (SAS Institute). For all statistical tests, results were considered significant at $\mathrm{p}<0.05$.

\section{RESULTS}

\section{Oiling status and identification of oil source}

Cutaneous swab samples from 492 individual oiled or suspected oiled turtles were analyzed for petroleum hydrocarbons (including petroleum biomarkers) and examined for potential sources (Table 1). Most of these animals $(\mathrm{n}=448)$ were surface-pelagic juveniles collected alive during offshore rescue of turtles from pelagic habitat. The rest of the sampled turtles were found as strandings, except for 3 turtles that were recovered by vessels skimming oil during the spill. Sampled external material was confirmed to be petroleum and matched with DWH oil for all heavily oiled turtles, $94 \%$ (44/47) of moderately oiled turtles, $78 \%$ (67/86) of lightly oiled and $13 \%(34 / 262)$ of minimally oiled turtles. Notably, petroleum was confirmed on an additional $20 \%(51 / 262)$ of minimally oiled turtles and $11 \%$ (9/86) of lightly oiled turtles, but the amount of material was insufficient to establish the oil source. Only 6 turtles were found to

Table 1. Results of chemical analysis of external samples from oiled sea turtles by degree of visible oil coverage. 'Inconclusive detection result' represents samples that contained non-petroleum contamination and traces of hydrocarbons. Based on the analysis conducted, it was not possible to conclusively attribute the presence of hydrocarbons to the presence of petroleum oil, due to insufficient quantity of hydrocarbons in the samples. BPDWH: BP Deepwater Horizon

\begin{tabular}{|c|c|c|c|c|c|c|}
\hline & $\begin{array}{l}\text { Minimally } \\
\text { oiled }\end{array}$ & $\begin{array}{c}\text { Lightly } \\
\text { oiled }\end{array}$ & $\begin{array}{c}\text { Moderately } \\
\text { oiled }\end{array}$ & $\begin{array}{l}\text { Heavily } \\
\text { oiled }\end{array}$ & Unknown & Total \\
\hline Petroleum oil confirmed: derived from BPDWH & 34 & 67 & 44 & 68 & 8 & 221 \\
\hline Petroleum oil confirmed: not derived from BPDWH & 3 & 3 & 0 & 0 & 0 & 6 \\
\hline Petroleum oil confirmed: source inconclusive & 2 & 2 & 2 & 0 & 1 & 9 \\
\hline Petroleum oil confirmed: insufficient quantity for comparison & 51 & 9 & 1 & 0 & 3 & 62 \\
\hline Petroleum oil not detected by analysis conducted & 92 & 2 & 0 & 0 & 7 & 101 \\
\hline Inconclusive detection result & 80 & 3 & 0 & 0 & 10 & 93 \\
\hline Total & 262 & 86 & 47 & 68 & 29 & 492 \\
\hline
\end{tabular}


have oil on them that definitively did not originate from the DWH spill, 4 of which were found near one another off the southwestern coast of Louisiana.

A total of 14 stranded turtles were reported as oiled or suspect oiled in 2010 and 2011. All of these turtles were either of indeterminate degree of oiling or were minimally oiled. The observed external material was confirmed to be petroleum in 6 instances and the source could be concluded in 3 cases -2 were DWH oil and 1 was another source. Both of the stranded turtles with DWH oil on them were found in 2011, and included the last sea turtle confirmed to be externally oiled with DWH oil, which was found in Jefferson Parish, Louisiana, on 23 October 2011.

\section{Analysis of postmortem samples for PAHs, PAH metabolites and DOSS}

PAH concentrations and patterns in gastroenteric and tissue samples

Wide ranges of $\mathrm{PAH}$ concentrations were determined in the sea turtle tissues, with the highest sum PAHs determined in turtle esophagus (10000 to $360000 \mathrm{ng} \mathrm{g}^{-1}$ wet wt), followed by enteric tissue and contents (4.8 to $15000 \mathrm{ng} \mathrm{g}^{-1}$ wet wt), liver (4.7 to $560 \mathrm{ng} \mathrm{g}^{-1}$ wet wt), lung (2.7 to $130 \mathrm{ng} \mathrm{g}^{-1}$ wet wt), colon contents ( 3.9 to $57 \mathrm{ng} \mathrm{g}^{-1}$ wet wt) and feces (6.8 to $44 \mathrm{ng} \mathrm{g}^{-1}$ wet wt) (Table 2). Similarly, wide ranges of percent lipid values were measured in the samples (esophagus, 1.0 to $10 \%$; enteric tissue and contents, 0.1 to $15 \%$; liver, 0.5 to $30 \%$; lung, 0.2 to $1.6 \%$; colon contents, 0.1 to $3.9 \%$; feces, 0.6 to $9.4 \%$ ) (Table S1 in the Supplement). A single gastric content sample collected from a non-visibly oiled Kemp's ridley (RAW2010061002) was also analyzed that had relatively low levels of sum PAHs (8.5 $\mathrm{ng} \mathrm{g}^{-1}$ wet wt) and a percent lipid value of $1.9 \%$. Similarly, low concentrations of sum PAHs (9.4 $\mathrm{ng} \mathrm{g}^{-1}$ wet wt) were also measured in the corresponding liver of this turtle.

Externally oiled turtles had higher mean concentrations of sum PAHs in tissues compared to the mean values in unoiled turtles (Table 2). For example, the mean enteric sum PAH concentration of oiled turtles $\left(3100 \pm 6100 \mathrm{ng} \mathrm{g}^{-1}\right.$ wet $\mathrm{wt}$, mean $\left.\pm \mathrm{SD}\right)$ was 2 orders of magnitude higher than for unoiled turtles $(31 \pm$ $100 \mathrm{ng} \mathrm{g}^{-1}$ wet wt). The mean sum PAHs measured in liver $\left(140 \pm 210 \mathrm{ng} \mathrm{g}^{-1}\right.$ wet wt) and lung $(34 \pm 49 \mathrm{ng}$ $\mathrm{g}^{-1}$ wet wt) samples of oiled turtles were approximately an order of magnitude higher than the mean values of non-oiled turtles (liver, $14 \pm 7.1 \mathrm{ng} \mathrm{g}^{-1}$ wet

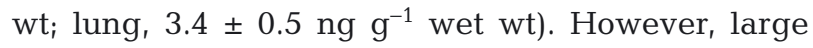

Table 2. Concentrations (ng g ${ }^{-1}$ wet wt) of sum low molecular weight polycyclic aromatic hydrocarbons (LMWAHs), sum high molecular weight polycyclic aromatic hydrocarbons (HMWAHs) and sum polycyclic aromatic hydrocarbons (PAHs) measured in gastroenteric and tissue samples of postmortem sea turtles from the northern Gulf of Mexico in response to the Deepwater Horizon oil spill. Values given as mean $\pm \mathrm{SD}$ or as a range. <LOQ: less than the lower limits of quantitation. For statistical analyses, a value of zero was used for $<$ LOQ. Statistical analyses were not conducted for colon content and feces, as samples from a single oiled turtle were analyzed. Esophageal samples consisted almost entirely of oil. ${ }^{*} p<0.05$ using 1-way ANOVA and Tukey-Kramer HSD test

\begin{tabular}{|c|c|c|}
\hline Sample type & Visibly oiled & Unoiled \\
\hline \multicolumn{3}{|l|}{ Colon content } \\
\hline Number (n) & 1 & 16 \\
\hline Sum LMWAHs & 42 & $11 \pm 6.4$ \\
\hline Sum LMWAHs & 42 & $3.9-22$ \\
\hline Sum HMWAHs & 15 & $4.1 \pm 4.1$ \\
\hline Sum HMWAHs & 15 & $<\mathrm{LOQ}-10$ \\
\hline Sum PAHs & 57 & $16 \pm 9.7$ \\
\hline Sum PAHs & 57 & $3.9-24$ \\
\hline \multicolumn{3}{|l|}{ Enteric content } \\
\hline Number (n) & 6 & 27 \\
\hline Sum LMWAHs* & $2500 \pm 5200$ & $25 \pm 77$ \\
\hline Sum LMWAHs & 18-13000 & $4.3-410$ \\
\hline Sum HMWAHs ${ }^{*}$ & $550 \pm 940$ & $5.9 \pm 23$ \\
\hline Sum HMWAHs & $17-2400$ & $<\mathrm{LOQ}-120$ \\
\hline Sum PAHs* & $3100 \pm 6100$ & $31 \pm 100$ \\
\hline Sum PAHs & 39-15000 & $4.3-530$ \\
\hline \multicolumn{3}{|l|}{ Esophageal } \\
\hline Number (n) & 6 & 0 \\
\hline Sum LMWAHs & $160000 \pm 110000$ & - \\
\hline Sum LMWAHs & $7900-300000$ & - \\
\hline Sum HMWAHs & $32000 \pm 22000$ & - \\
\hline Sum HMWAHs & 2200-59000 & - \\
\hline Sum PAHs & $190000 \pm 130000$ & - \\
\hline Sum PAHs & $10000-360000$ & - \\
\hline \multicolumn{3}{|l|}{ Feces } \\
\hline Number (n) & 1 & 6 \\
\hline Sum LMWAHs & 20 & $17 \pm 10$ \\
\hline Sum LMWAHs & 20 & $6.8-34$ \\
\hline Sum HMWAHs & 13 & $3.2 \pm 3.6$ \\
\hline Sum HMWAHs & 13 & $<\mathrm{LOQ}-10$ \\
\hline Sum PAHs & 33 & $20 \pm 14$ \\
\hline Sum PAHs & 33 & $6.8-44$ \\
\hline \multicolumn{3}{|l|}{ Liver } \\
\hline Number (n) & 10 & 58 \\
\hline Sum LMWAHs * & $130 \pm 200$ & $13 \pm 6.9$ \\
\hline Sum LMWAHs & $8.4-530$ & $4.7-48$ \\
\hline Sum HMWAHs * & $8.5 \pm 13$ & $0.6 \pm 0.7$ \\
\hline Sum HMWAHs & $<\mathrm{LOQ}-33$ & $<\mathrm{LOQ}-3.5$ \\
\hline Sum PAHs ${ }^{*}$ & $140 \pm 210$ & $14 \pm 7.1$ \\
\hline Sum PAHs & $8.4-560$ & $4.7-48$ \\
\hline \multicolumn{3}{|l|}{ Lung } \\
\hline Number (n) & 7 & 6 \\
\hline Sum LMWAHs ${ }^{*}$ & $31 \pm 45$ & $3.4 \pm 0.5$ \\
\hline Sum LMWAHs & $2.7-120$ & $2.8-4.1$ \\
\hline Sum HMWAHs & $2.3 \pm 3.9$ & $<\mathrm{LOQ}$ \\
\hline Sum HMWAHs & $<\mathrm{LOQ}-8.7$ & $<\mathrm{LOQ}$ \\
\hline Sum PAHs ${ }^{*}$ & $34 \pm 49$ & $3.4 \pm 0.5$ \\
\hline Sum PAHs & $2.7-130$ & $2.8-4.1$ \\
\hline
\end{tabular}



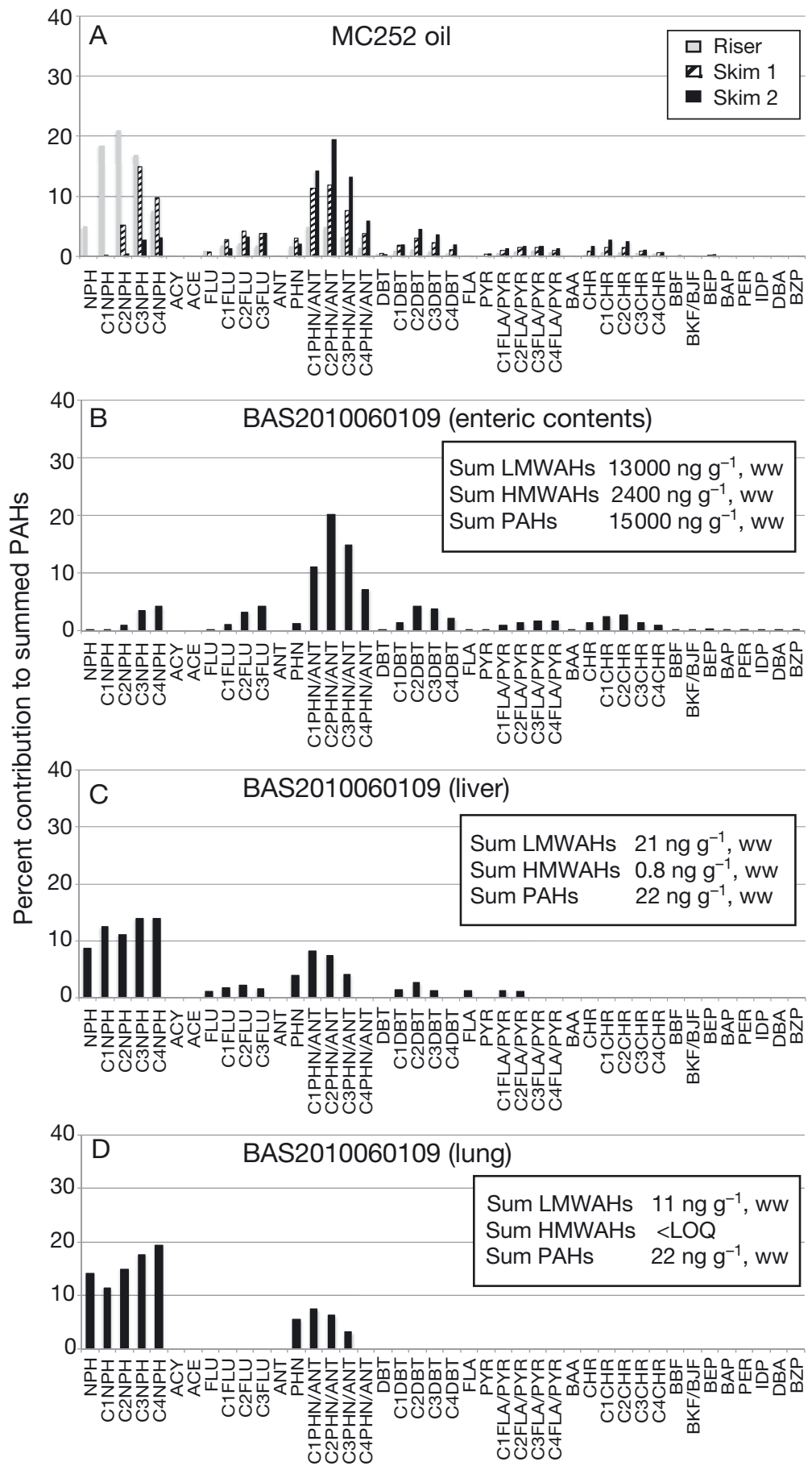

Fig. 1. Comparisons of percent contribution of individual and alkylated polycyclic aromatic hydrocarbons (PAHs) to (A) summed PAHs determined in Louisiana oil samples (MC252 riser oil, gray; a weathered MC252 oil sample collected by a skimmer in May 2010, striped; and a weathered MC252 oil sample collected by numerous skimmers in July 2010, black) to those determined in (B) enteric contents, (C) liver and (D) lung of a visibly oiled Kemp's ridley sea turtle (BAS2010060109) sampled in June 2010. Concentrations of summed low molecular weight PAHs (sum LMWAHs), summed high molecular weight PAHs (sum HMWAHs) and summed PAHs (sum PAHs) are summarized for each tissue. <LOQ: less than lower limit of quantitation standard deviations were associated with many of the mean values as a result of a wide range of concentrations for the samples analyzed.

Concentrations of PAHs varied in matched tissue samples of oiled and non-visibly oiled sea turtles. For example, sum PAHs (15000 $\mathrm{ng} \mathrm{g}^{-1}$ wet wt) measured in an enteric sample of a heavily oiled Kemp's ridley turtle (BAS2010060109) was more than 2 orders of magnitude higher than the concentrations in the matched liver $\left(22 \mathrm{ng} \mathrm{g}^{-1}\right.$ wet wt) and lung (11 $\mathrm{ng} \mathrm{g}^{-1}$ wet wt) samples from the same animal (Fig. 1). Interestingly, the enteric sample (Fig. 2B) collected from a non-visibly oiled loggerhead turtle (PAK2010072161) had PAH concentrations that were more than 50 times higher than those determined in the corresponding liver (Fig. 2C) and lung (Fig. 2D). However, analyses of biliary PAH metabolites of this loggerhead did not indicate recent exposure to a crude oil, as the fluorescent chromatographic pattern (Fig. 3C) did not resemble those of a visibly oiled turtle (Fig. 3A) and crude-oil-dosed Atlantic salmon (Fig. 3B). As variable percent lipid concentrations in tissue samples were also observed, the relationships between PAH concentrations and lipid content were examined. Percent lipid values were significantly correlated $(\mathrm{p}<$ 0.05 ) to sum LMWAHs and sum PAHs for all tissues except enteric samples ( $p>0.490$ ). However, these relationships were weak $\left(\mathrm{r}^{2}<0.53\right)$ except for fecal sum LMWAHs $\left(r^{2}=0.9297\right)$ and sum HMWAHs $\left(r^{2}=0.8028\right)$. No other significant relationships $(p>0.05)$ were found.

Contributions of LMWAHs - PAHs closely associated with petroleum - to sum PAHs measured in internal samples of turtles were examined to help determine if they were derived from petroleum or pyrogenic sources. In all gastroenteric and tissue samples of heavily oiled turtles, sum LMWAHs were the major contributors to sum PAHs, with the percent contribution ranging from 71 to $100 \%$ (Table S1). Similarly, tissues of other oiled turtles also had high percent sum LMWAH values ranging from 61 to $100 \%$, except an enteric sample $(46 \%)$ of an oiled Kemp's ridley turtle (CDD2011032901). In unoiled turtles, sum 


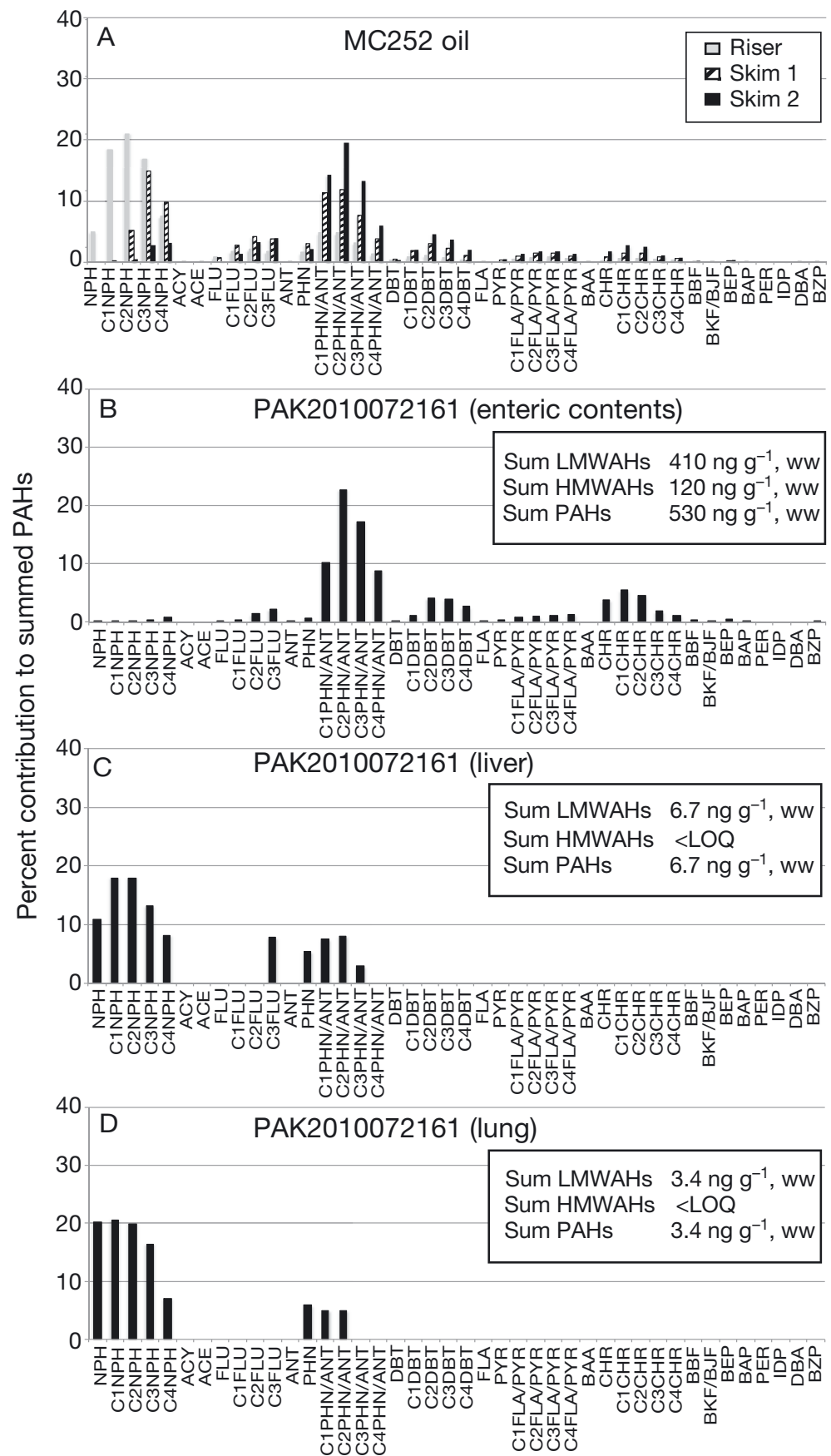

Fig. 2. Comparisons of percent contribution of individual and alkylated polycyclic aromatic hydrocarbons (PAHs) to (A) summed PAHs determined in Louisiana oil samples (MC252 riser oil, gray; a weathered MC252 oil sample collected by a skimmer in May 2010, striped; and a weathered MC252 oil sample collected by numerous skimmers in July 2010, black) to those determined in (B) enteric contents, (C) liver and (D) lung of an unoiled loggerhead sea turtle (PAK2010072161) sampled in July 2010. Note the much higher concentrations of PAHs in the enteric contents sample compared to the matching liver and lung samples. Concentrations of summed low molecular weight PAHs (sum LMWAHs), summed high molecular weight PAHs (sum HMWAHs) and summed PAHs (sum PAHs) are summarized for each tissue. <LOQ: less than the lower limit of quantitation. See Fig. 1 for $x$-axis acronym definitions
LMWAHs contributed 47 to $100 \%$ to sum PAHs. In lung and liver samples, the mean percent sum LMWAHs contributing to sum PAHs (98 \pm 3.3 and $95 \pm 4.4 \%$, respectively) were elevated compared to the mean values determined for samples of enteric content $(87 \pm 12 \%)$, feces $(84 \pm 13 \%)$, esophagus $(82 \pm 2.6 \%)$ and colon content $(79 \pm 16 \%)$ (Table S1).

Examination of the PAH composition patterns of the sea turtle tissues indicated exposure to petroleum as well as to other sources of PAHs. The esophageal samples of visibly oiled Kemp's ridley turtles (Fig. 4B,C) had PAH patterns similar to weathered MC252 oil patterns (Fig. 4A) (patterns derived from $\mathrm{PAH}$ concentration data for MC252 oil samples reported previously in Incardona et al. 2014), with both tissue and weathered oil samples showing losses of naphthalene (NPH) and C1-naphthalenes and increased contributions of C2-, C3- and C4-naphthalenes to sum PAHs. Similarly, PAH composition patterns of other matched tissues (Fig. 1B-D) of heavily oiled turtles were also similar to those of weathered MC252 oil (Fig. 1A). In certain tissues of oiled turtles (Fig. 5B-D), the PAH composition patterns contained higher proportions of 4- and 5-ring PAHs (e.g. chrysene, benzo(a)pyrene $[\mathrm{BaP}]$, perylene) than did the weathered MC252 oil samples (Fig. 5A).

\section{PAH metabolites in bile}

Variable concentrations of fluorescent PAH metabolites were measured in bile of oiled and non-visibly oiled sea turtles, with phenanthrene (PHN) and NPH equivalents ranging from 110000 to 510000 and 160000 to $560000 \mathrm{ng} \mathrm{g}^{-1}$ bile wet $\mathrm{wt}$, respectively, in visibly oiled turtles, and PHN and NPH equivalents in non-visibly oiled animals ranging from 5400 to 30000 and 23000 to 140000 ng $\mathrm{g}^{-1}$ bile wet $\mathrm{wt}$, respectively. The biliary $\mathrm{BaP}$ equivalent concentrations ranged from 1100 to $4200 \mathrm{ng} \mathrm{g}^{-1}$ bile wet wt in visibly oiled turtles and 65 to $30000 \mathrm{ng} \mathrm{g}^{-1}$ bile wet wt in unoiled turtles. Protein-corrected PHN and NPH equivalents ranged from 2400 to 22000 and 3500 to $27000 \mathrm{ng} \mathrm{mg}^{-1}$ protein, respectively, in visibly oiled animals. In non-visibly oiled turtles, these values ranged from 180 to 

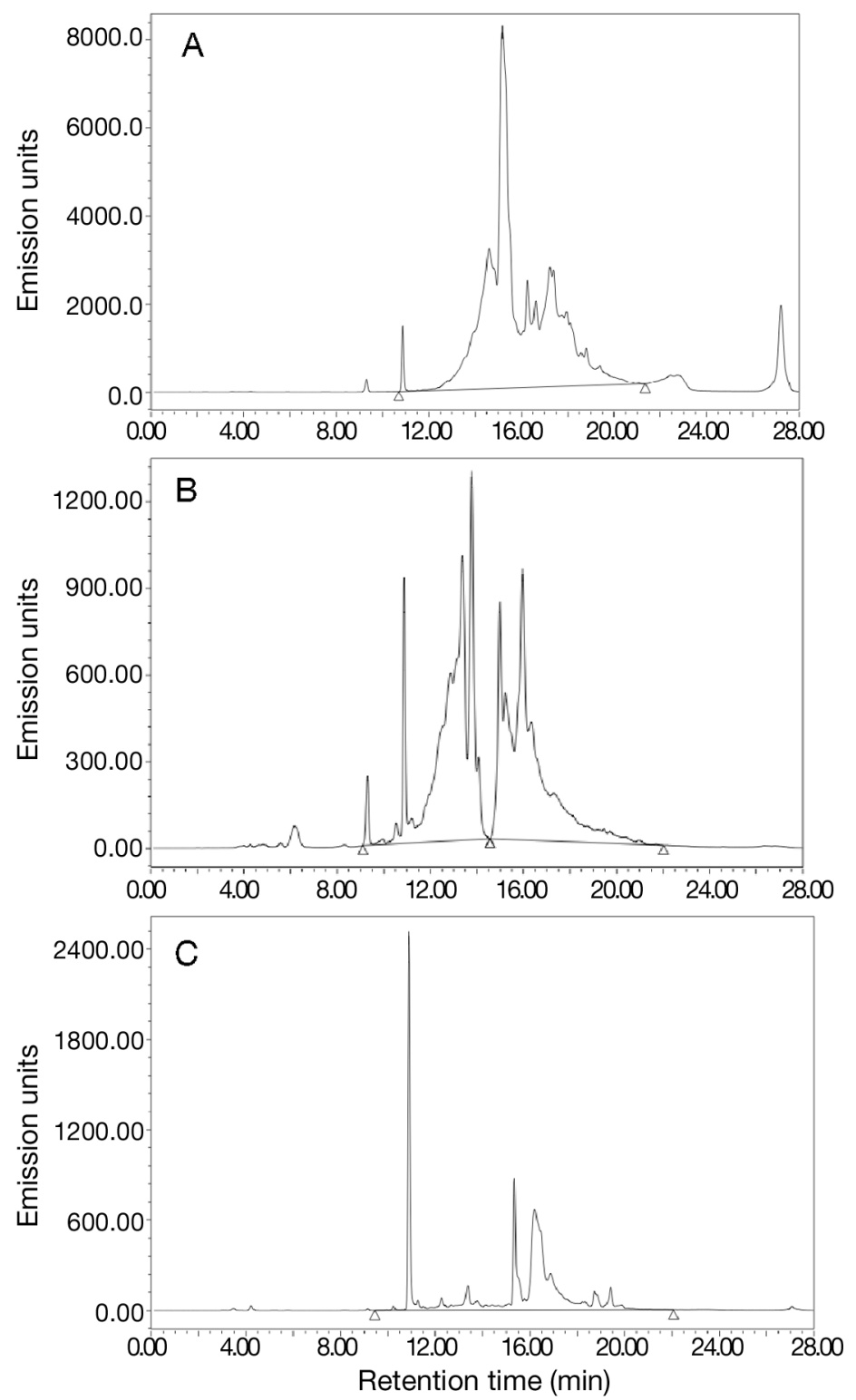

Fig. 3. Biliary fluorescent polycyclic aromatic hydrocarbon (PAH) metabolite chromatograms collected at the phenanthrene (PHN) wavelength pair for (A) a visibly oiled Kemp's ridley sea turtle (BAS2010060110) collected in the northern Gulf of Mexico during the Deepwater Horizon oil spill, (B) Atlantic salmon exposed to $25 \mathrm{ppm}$ Monterey crude oil in water for $48 \mathrm{~h}$ and (C) an unoiled loggerhead sea turtle (PAK2010072161) collected in the northern Gulf of Mexico during the Deepwater Horizon oil spill. Note the characteristic 2-hump (9 to 15 and 15 to $21 \mathrm{~min}$ ) chromatographic pattern of oil exposure in both the salmon and oiled sea turtle, as compared with the pattern of multiple peaks with no humps associated with the unoiled turtle (PAK2010072161)

1700 and 980 to $11000 \mathrm{ng} \mathrm{mg}^{-1}$ protein, respectively. Protein-corrected $\mathrm{BaP}$ equivalent concentrations ranged from 57 to $140 \mathrm{ng} \mathrm{mg}^{-1}$ protein in visibly oiled turtles and 1.5 to $1200 \mathrm{ng} \mathrm{mg}^{-1}$ protein in unoiled tur- tles. Significantly different $(p<0.05)$ mean $( \pm S D)$ concentrations of PHN, NPH and BaP equivalents $\left(\log _{10}\right.$-transformed) were measured in bile of oiled turtles compared to non-visibly oiled animals (Fig. 6).

Chromatographic HPLC-F patterns were examined to suggest a possible source of PAH exposure (e.g. pyrogenic or petrogenic chemical contaminants) (Krahn et al. 1993). Visibly oiled sea turtles had chromatographic patterns (example of pattern shown in Fig. 3A) that were similar to those observed in bile of Atlantic salmon exposed to Monterey crude oil (Fig. 3B), as well as the patterns of bile from harbor seals that were visibly oiled by the Exxon Valdez oil spill (Krahn et al. 1993). Although non-oiled turtles had measurable levels of PAH metabolites in their bile, their HPLC-F chromatographic patterns (Fig. 3C) did not resemble those of visibly oiled turtles, as noted by the absence of the characteristic 2-hump (12 to 15 and 15 to $21 \mathrm{~min}$ ) chromatographic pattern of oil exposure in bile from both the visibly oiled Kemp's ridley sea turtles and crude-oil-exposed Atlantic salmon.

Concentrations of individual OHPAHs determined by LC-MS/MS in bile collected from 20 turtles were generally less than the LOQ $\left(<12 \mathrm{ng} \mathrm{g}^{-1}\right.$ wet wt) or, when detected, were low ( $\leq 35 \mathrm{ng} \mathrm{g}^{-1}$ wet wt) (data not shown). The highest levels of OHPAHs were measured in 2 visibly oiled Kemp's ridley turtles (BAS2010060109 and BAS2010060605) and included 1-, 2- and 3-hydroxyphenanthrene. In addition, 1and 2-hydroxyphenanthrene were also measured in a bile sample collected from a non-visibly oiled Kemp's ridley turtle (NME2010082301), but the concentrations of these 2 OHPAHs were near the LOQ for each compound.

\section{DOSS concentrations}

Of the 171 samples from 78 individual sea turtles analyzed for DOSS, only 1 sample had concentrations above the LOQ (ranging from $<100$ to $<5100 \mathrm{ng}$ $\mathrm{g}^{-1}$ wet wt). A sample of esophageal contents from a heavily oiled sea turtle (SDD201006105) had a concentration of $1800 \mathrm{ng} \mathrm{g}^{-1}$ wet wt (Table S1).

\section{DISCUSSION}

The chemical analyses conducted for this study demonstrated both external and internal exposure of protected sea turtles to DWH oil, and are the most complete information of this kind for sea turtles 


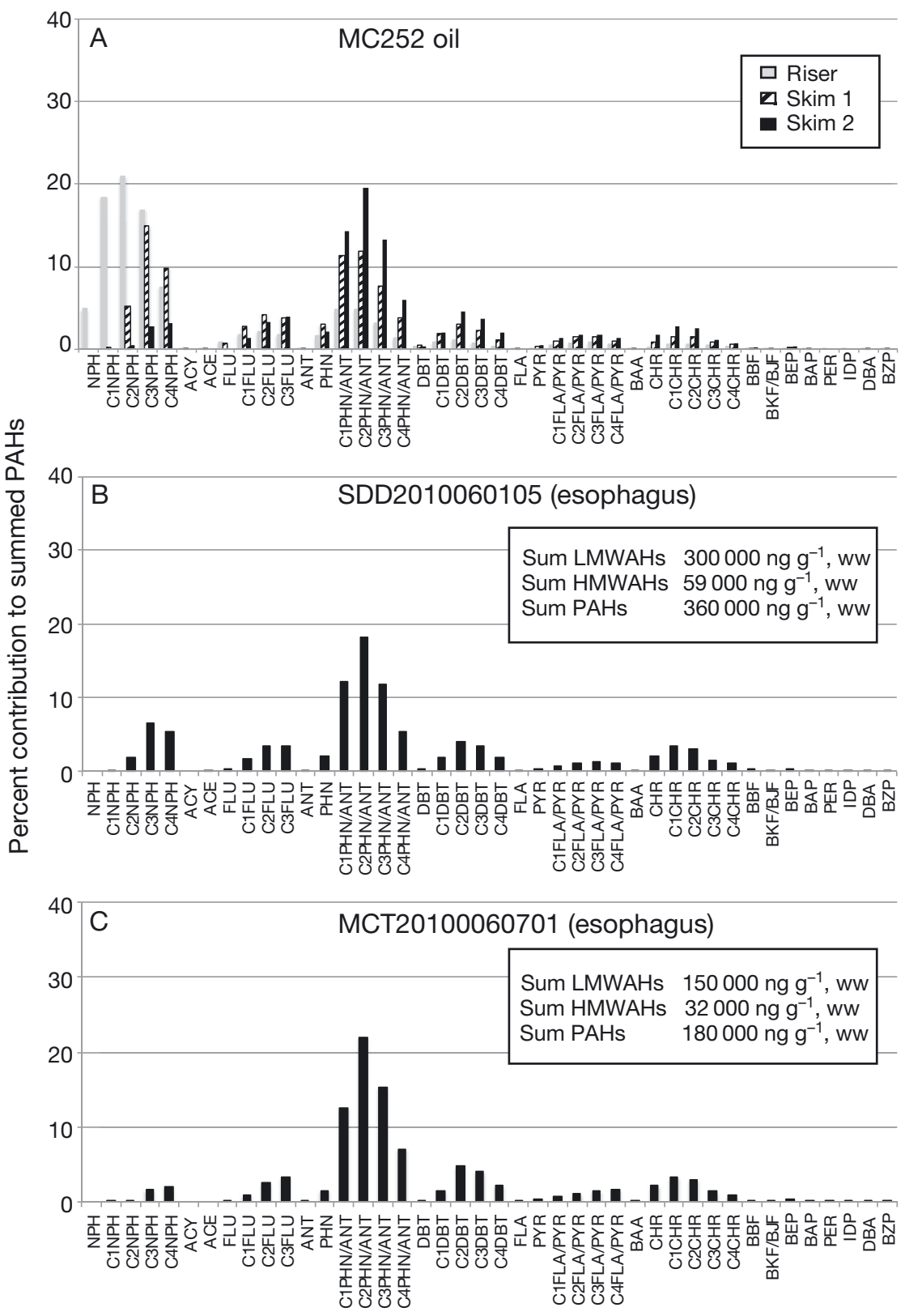

Fig. 4. Comparisons of percent contribution of individual and alkylated polycyclic aromatic hydrocarbons (PAHs) to (A) summed PAHs determined in Louisiana oil samples (MC252 riser oil, gray; a weathered MC252 oil sample collected by a skimmer in May 2010, striped; and a weathered MC252 oil sample collected by numerous skimmers in July 2010, black) to those determined in esophageal samples of 2 heavily oiled Kemp's ridley sea turtles sampled in (B) June 2010 (SDD2010060105) and (C) June 2010 (MCT20100060701). Concentrations of summed low molecular weight PAHs (sum LMWAHs), summed high molecular weight PAHs (sum HMWAHs) and summed PAHs (sum PAHs) are summarized for each issue. See Fig. 1 for $x$-axis acronym definitions these analyses are an important element of defensible documentation of exposure under the NRDA process. In addition, internal concentrations of PAHs and metabolites measured in sea turtles under a natural exposure scenario contribute to a very limited body of such information.

\section{External oil on sea turtles matched DWH source}

External samples collected from most of the heavily and moderately oiled sea turtles had conclusive chemical confirmation and matched DWH oil; however, identity of material from some lightly oiled turtles and over $60 \%$ of minimally oiled turtles could not be confirmed. These results suggest that the threshold of detection for the methodology used in this study was related to degree of oiling. The small size $(<25 \mathrm{~cm}$ carapace length) of surface pelagic juveniles, which were the predominant life stage sampled, and the tenacious adherence of oil to keratin limited the volumes of collected material, especially for some minimally and lightly oiled turtles. In addition, oil can absorb into and adhere to the sampling devices (i.e. gauze, wooden tongue depressors) used in this study, making it difficult to extract a quantity of petroleum sufficient to overcome analytical thresholds.

\section{Evidence of PAH absorption and variability in visibly oiled sea turtles}

Analysis of bile samples confirmed internal exposure and absorption of PAHs, as well as metabolism in externally oiled sea turtles, but results recovered during an oil spill. Our findings bolster visual observations and other data related to petroleum exposure by providing analytical chemical confirmation. Although the conclusions drawn from this study are relatively straightforward and intuitive, were variable among animals. Individual hydroxylated PHN metabolites were measured in 2 of 5 visibly oiled Kemp's ridley turtles. Oiled turtles had significantly higher concentrations of fluorescent $\mathrm{PAH}$ metabolites (both non-protein and protein-corrected 

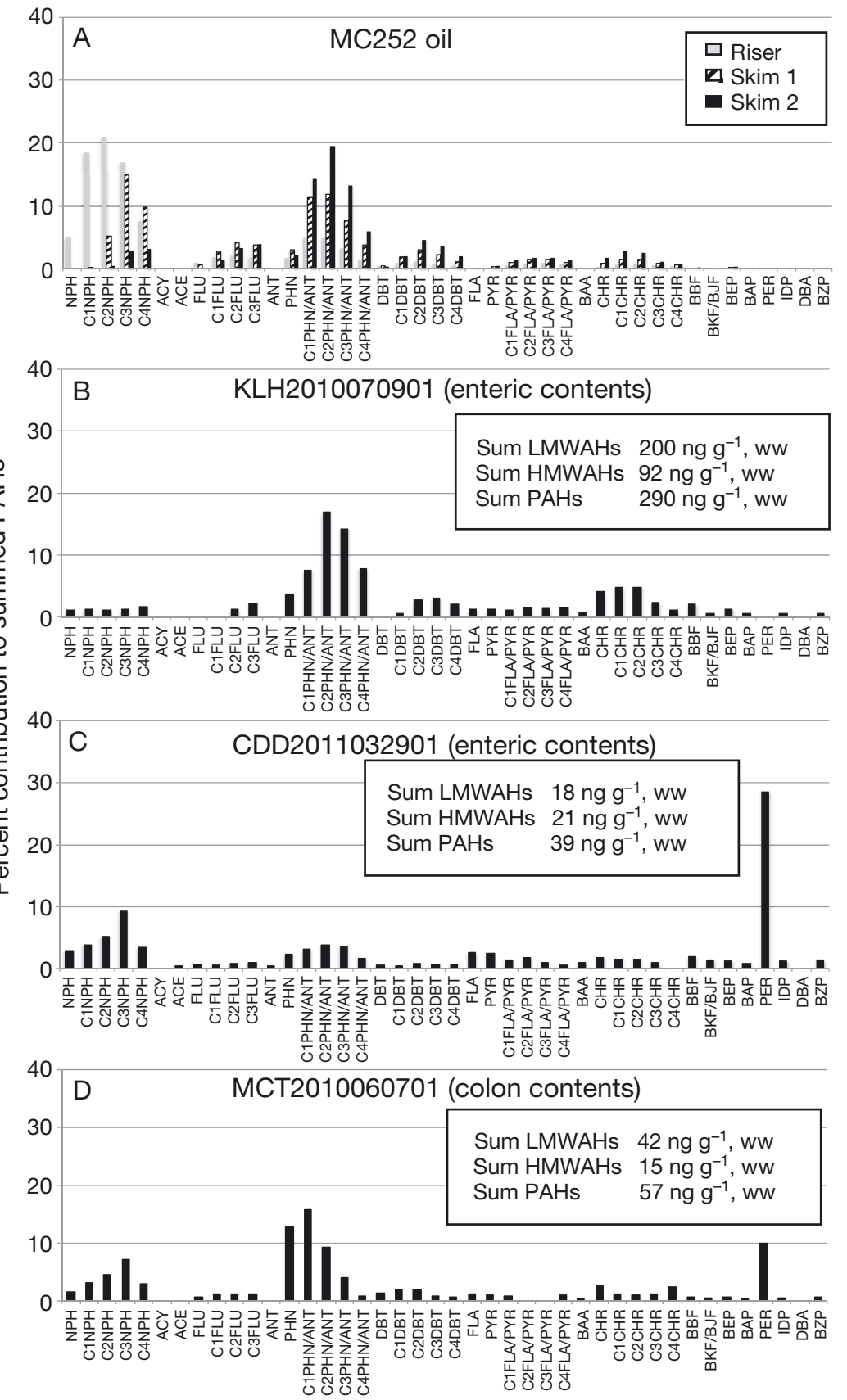

Fig. 5. Comparisons of percent contribution of individual and alkylated polycyclic aromatic hydrocarbons (PAHs) to (A) summed PAHs determined in Louisiana oil samples (MC252 riser oil, gray; a weathered MC252 oil sample collected by a skimmer in May 2010, striped; and a weathered MC252 oil sample collected by numerous skimmers in July 2010, black) to those determined in (B) enteric contents of a lightly oiled Kemp's ridley sea turtle (KLH2010070901) sampled in July 2010, (C) enteric contents of an oiled (unknown degree of oiling) Kemp's ridley (CDD2011032901) sampled in March 2011 and (D) colon contents of a heavily oiled Kemp's ridley (MCT2010060701) sampled in June 2010. Note the higher proportions of chrysenes (CHR), benzo(a)pyrene (BaP) and perylene (PER) in the turtle tissues compared to the riser and weathered MC252 oil. Concentrations of summed low molecular weight PAHs (sum LMWAHs), summed high molecular weight PAHs (sum HMWAHs) and summed PAHs (sum PAHs) are summarized for each tissue. See Fig. 1 for $x$-axis acronym definitions values) compared to unoiled turtles (Fig. 6). Notably, the fluorescent PAH metabolite equivalents measured in bile of oiled sea turtles were higher than those measured in bile from harbor seals collected during a subsistence survey in Alaska in 1989 to 1990 after the 1989 Exxon Valdez oil spill (Varanasi et al. 1993). Some of the variability in bile analytes among oiled turtles may be due to differences in dose and timing of exposure; however, all heavily oiled turtles had evidence of ongoing exposure at the time of death (i.e. all were covered in oil and had oil within their gastrointestinal tract).

PAHs are generally categorized as petrogenic (derived from petroleum sources such as crude oil and tar sands) or pyrogenic (derived from incomplete burning of fossil fuels, wood products, etc.) (Collier et al. 2014). Petrogenic PAHs usually contain high proportions of low molecular weight PAHs that have 2 to 3 fused aromatic rings, including high proportions of alkylated PAHs (containing at least 1 or more methyl, ethyl or other alkylated group in place of a hydrogen atom on the ring). Pyrogenic PAHs, on the other hand, have higher proportions of high molecular weight PAHs that contain 4 to 7 fused aromatic rings that do not usually have alkyl-substituted groups (Collier et al. 2014). Analyses of environmental samples collected from the northern GoM indicate input of petrogenic and pyrogenic PAHs into this region (Overton et al. 2004, Iqbal et al. 2007, Mitra et al. 2009). In our study, $\mathrm{PAH}$ concentrations in gastroenteric contents were consistently elevated in oiled turtles, confirming that turtles were exposed to DWH oil via multiple pathways. Heavily oiled turtles had high levels of PAHs (Table 2), and PAH composition patterns of gastroenteric and liver samples (Fig. 1B,C) were similar to those of weathered MC252 oil (see Fig. 1A), with both sample matrices containing high proportions of alkylated naphthalenes, fluorenes and phenanthrenes/anthracenes. As expected, sea turtles that were identified as lightly or 

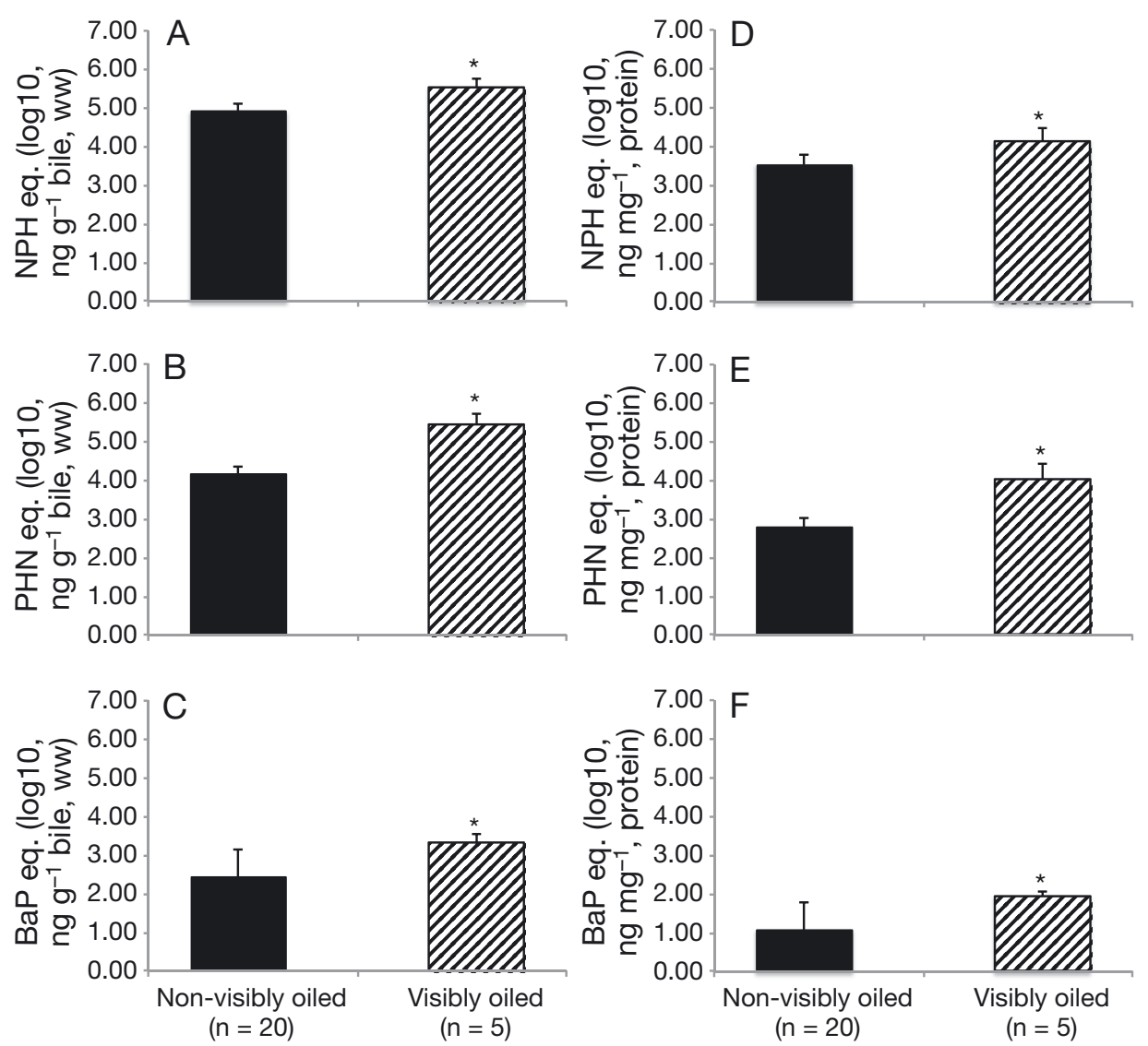

Fig. 6. Mean \pm SD non-proteincorrected $\log _{10}$-transformed concentrations of fluorescent polycyclic aromatic hydrocarbon (PAH) metabolites measured in bile of oiled (striped) and unoiled (black) sea turtles at (A) naphthalene (NPH) wavelength pair $(292 / 335 \mathrm{~nm})$, (B) phenanthrene (PHN) wavelength pair $(260 / 380 \mathrm{~nm})$ and $(\mathrm{C})$ benzo(a)pyrene (BaP) wavelength pair $(380 / 430 \mathrm{~nm})$. Mean protein-corrected $\log _{10^{-}}$ transformed concentrations of fluorescent polycyclic aromatic hydrocarbon (PAH) metabolites measured in bile of oiled and unoiled sea turtles at (D) NPH wavelength pair (292/335 nm), (E) PHN wavelength pair (260/380 $\mathrm{nm})$ and (F) $\mathrm{BaP}$ wavelength pair (380/430 nm). ${ }^{*} \mathrm{p}<0.05$ using Tukey-Kramer HSD test minimally oiled with no oil noted in the mouth or esophagus, had lower levels of PAHs in their gastroenteric samples compared to similar measurements in the heavily oiled animals. Further, the composition patterns of the lightly or minimally oiled turtles had higher proportions of HMWAHs (see Fig. 4 and Table S1 in the Supplement) compared to those of weathered MC252 oil or heavily oiled turtles, suggesting exposure to pyrogenic sources of PAHs. Liver samples of oiled sea turtles also indicated PAH exposure, but the concentrations were not as high as those in the matched gastroenteric samples, and the PAH composition patterns deviated from those of the MC252 oil samples (Fig. 1). These findings are likely due to metabolism of PAHs in sea turtles.

\section{Tissue differences in PAH concentrations and implications for metabolism in sea turtles}

Although the relationships between PAH concentrations and corresponding percent lipid values in the turtle tissues were generally not significant $(p \geq$ $0.05)$, or were significant $(p<0.05)$ but not particu- larly strong $\left(\mathrm{r}^{2}<0.53\right)$, tissue samples with higher lipid content (e.g. liver) generally had higher $\mathrm{PAH}$ levels compared to those with lower percent lipid values (e.g. lung), which is consistent with previous PAH exposure studies in fish (Bruner et al. 1994, Meador et al. 1995, Hellou \& Leonard 2004). For example, Hellou et al. (2002) fed rainbow trout Oncorhynchus mykiss a diet spiked with 4 PAHs over a 4 mo period and reported that fatty tissue and internal organs (i.e. higher lipid content tissues) had concentrations of PAHs that were 130 to 260 times higher than those measured in lowlipid blood samples at week 19 of exposure. In the current study, a higher mean percent sum LMWAHs contributing to sum PAHs was determined for sea turtle liver samples compared to those of matched gastroenteric samples. Xenobiotics, including PAHs, are extensively metabolized by fish and other vertebrates (Varanasi et al. 1989, Parkinson 2001), which is likely the case for sea turtles as well. Results from laboratory exposure and field studies have shown that metabolism of LMWAHs (e.g. NPH) is not as efficient as metabolism of HMWAHs (e.g. BaP) in some species of fish and birds (Roubal et al. 1977, Varanasi \& Gmur 
1981, Jonsson et al. 2004, Troisi et al. 2006). Data collected in the current study clearly demonstrated that externally oiled turtles had absorbed petroleum-related PAHs via ingestion as well as inhalation (based on gastrointestinal and lung PAH findings, respectively), and that they had metabolized these compounds in the liver to more polar fluorescent aromatic compounds that were measured in their bile.

\section{Predominance of low molecular weight PAHs consistent with exposure to petroleum}

Sum LMWAHs were the major contributors to sum PAHs in tissues of heavily oiled turtles (Table S1). Reddy et al. (2012) conducted a study to determine the composition of oil and gas released into waters of the GoM during the DWH oil spill. Similar to the PAH analytical findings of other crude oils and bunker fuels (Wang et al. 2003, Incardona et al. 2012, Jung et al. 2013), the authors reported that the MC252 crude oil had higher amounts of 2- and 3-ring LMWAHs (e.g. naphthalenes, fluorenes, phenanthrenes) compared to 4- and 5-ring HMWAHs (e.g. chrysenes, benz(a)anthracenes). Similarly, lightly to moderately oiled turtles analyzed in the current study also had high percentages of sum LMWAHs (61 to $100 \%$ of sum PAHs), except for an enteric contents sample of a Kemp's ridley (CDD2011032901) (sum LWMAHs was 46\% of sum PAHs). In this gastrointestinal sample, perylene contributed $52 \%$ to the sum HMWAHs and $28 \%$ to the sum PAHs. Thus, for animals exposed to oil originating from the MC252 wellhead or from other sources of petroleum, higher proportions of LMWAHs would be expected in their tissues compared to HMWAHs.

\section{Results do not suggest cryptic exposure in unoiled stranded turtles}

Large numbers of dead, non-visibly oiled sea turtles were found stranded within the northern GoM concurrent with the DWH oil spill and in subsequent years (Stacy 2015). Many of these turtles had postmortem findings consistent with drowning in commercial fisheries or traumatic injuries, but there was general concern that these animals may have been exposed to oil and affected by the spill in some way. In addition, as oil reached inshore areas where stranded turtles likely originated, there were con- cerns related to ongoing exposure after surface oiling was no longer evident.

Much lower concentrations of biliary PAH metabolites were measured in unoiled sea turtles compared to those of visibly oiled stranded turtles. Concentrations of individual OHPAHs measured in bile were below the LOQ in all but 1 non-visibly oiled stranded turtle. However, the biliary concentrations of the detected OHPAHs determined for this animal were quite low-near the LOQ for each analyte. Furthermore, chromatographic HPLC-F patterns in unoiled stranded turtles were different from those of oiled stranded turtles.

More variability was found in PAHs in tissue and gastroenteric content samples of unoiled stranded turtles; however, results generally showed lower concentrations of sum LMWAHs and sum PAHs, and very low sum $\mathrm{HMWAH}$ concentrations compared to oiled stranded turtles. In unoiled turtles, sum LMWAHs were the major contributors to sum PAHs $(>55 \%)$ in all tissues except a colon content sample $(47 \%)$ of a Kemp's ridley turtle (KLS2011043001) (Table S1). In this sample, fluoranthene and pyrene contributed approximately $35 \%$ to sum HMWAHs and $20 \%$ to sum PAHs. These higher molecular weight PAHs are components of crude oil and bunker fuel, but are also associated with pyrogenic sources of PAHs (da Silva \& Bicego 2010, Hatlen et al. 2010, Incardona et al. 2012, Collier et al. 2014, Johnson et al. 2015). Perylene comprised a high proportion of PAHs in some tissue samples (including visibly oiled turtles). It is likely that these turtles were exposed to a biogenic source via benthic feeding behavior rather than to a petrogenic source of perylene, as relatively low proportions of this compound have been reported in crude oils and bunker fuels (da Silva \& Bicego 2010, Hatlen et al. 2010, Incardona et al. 2012). Perylene has been found to occur in peats and marine sediments from various regions of the world, especially in reducing sediments most likely as a result of anaerobic breakdown of organic compounds (Venkatesan 1988).

Potential exposure to crude oil was found in 1 nonvisibly oiled loggerhead (PAK2010072161), which drowned as a result of dredging activities north of the Chandeleur Islands in July 2010, after surface oil was reported in this region during the DWH spill. Relatively high concentrations of PAHs were found in a sample of enteric contents (Fig. 2B). Postmortem examination confirmed that this turtle had been foraging on benthic invertebrates and may have been exposed to petroleum through contaminated sediment or prey. The PAH composition pattern was sug- 
gestive of exposure to weathered oil and resembled the composition of weathered MC252 oil. Likewise, biliary PAH metabolite concentrations of this turtle indicated that it had been recently exposed to PAHs, but the corresponding HPLC-F qualitative data (chromatographic pattern shown in Fig. 3C) did not indicate exposure to a crude oil. Thus, results from this animal are considered inconclusive with regard to petroleum exposure.

Although baseline data on exposure of GoM sea turtles to PAHs are lacking, the results of analyses of bile, tissue and gastrointestinal content from unoiled stranded turtles may represent background exposure to a mixture of biogenic, petrogenic and pyrogenic sources of PAHs. Thus, we did not find clear evidence of widespread crude oil exposure in unoiled, stranded sea turtles found during the DWH spill or in 2011. These findings were consistent with field observations, which documented most oiled sea turtles distant from shore, and very few as beach-cast strandings (Stacy 2012). In general, strandings are most representative of mortality occurring closer to shore, and are not a good indicator of mortality occurring offshore (Hart et al. 2006). Furthermore, exposure in stranded turtles is not necessarily representative and may not be a good measure of population-level exposure, especially if petroleum has a patchy distribution in the environment and exposures were not sufficient to cause acute mortality.

\section{Limited evidence of exposure to dispersants}

The only detectable concentration of the dispersant component DOSS was measured in an esophageal sample from a heavily oiled Kemp's ridley (SDD2010060105) (see Table S1). This turtle was collected approximately 12 nautical miles offshore, where most applications of dispersants were reported to occur (Houma ICP Aerial Dispersant Group 2010). Our finding of DOSS levels below the LOQ for all other tissue and bile samples analyzed in the current study may be due to analytical limitations, habitat use and other factors. For example, certain esophageal and bile samples of sea turtles in the current study had relatively high LOQ values (ranging from 320 to $5100 \mathrm{ng} \mathrm{g}^{-1}$ wet wt) due to the small sample mass ( $<1 \mathrm{~g}$ ) compared to the LOQs (ranging from 100 to $220 \mathrm{ng} \mathrm{g}^{-1}$ wet wt) for samples having $>1 \mathrm{~g}$ mass available for the analyses. Thus, these turtles may have been exposed to DOSS, but at concentrations that were below our reported LOQ values. In addition, regardless of visible oiling status, we ex- pected to find low or non-detectable concentrations of DOSS in certain tissues of the turtles, as a previous laboratory exposure study on rainbow trout demonstrated rapid uptake of ${ }^{14} \mathrm{C}$-labeled $\mathrm{DOSS}$, with approximately $80 \%$ of the labeled compound accumulating in the bile compared to the trout carcass or blood samples after a $72 \mathrm{~h}$ static water exposure period (Goodrich et al. 1991). Similar to our turtle tissue findings, the DOSS concentrations measured in more than 8000 seafood specimens collected in federal waters of the northern GoM as part of the seafood safety response to the DWH spill were frequently below the LOQ or, when detected, were found at low concentrations (50 to $290 \mu \mathrm{g} \mathrm{g}^{-1}$ wet wt) (Ylitalo et al. 2012). Furthermore, most of the sea turtles that were not visibly oiled were size classes that typically inhabit continental shelf, or neritic areas. These larger neritic sea turtles are not expected to have had the same probability of dispersant exposure as surface-pelagic juvenile life stages (or leatherback turtles), which are found offshore where the greatest volume of dispersants were reported to be used during the DWH spill (Kujawinski et al. 2011). Recent laboratory studies have demonstrated that bio- and/or photo-degradation of DOSS is more rapid under surface water environmental conditions (e.g. higher temperature, increased light) than degradation under deep water conditions (e.g. lower temperature, reduced light) (Campo et al. 2013, Batchu et al. 2014); thus, DOSS exposure in surface-pelagic juvenile turtles may have been minimized or not occurred at all due to degradation, depending upon the timing of the surface application of DOSS and the turtle occurrence in the region. Information on exposure of turtles to DOSS degradation products, however, is unknown as these compounds were not measured in the current study.

In conclusion, analyses from the current study confirmed that most sea turtles observed to be oiled during the 2010 DWH spill had, in fact, been oiled by MC252 oil. Furthermore, results of chemical analyses of internal bile and tissue samples demonstrated that visibly oiled sea turtles from the northern GoM had higher internal concentrations of PAHs or fluorescent PAH metabolites compared to non-visibly oiled turtles, and that oil was taken up internally by turtles that were externally exposed to petroleum. In addition, the fluorescent PAH metabolite chromatographic patterns in bile of oiled turtles were consistent with exposure to a petrogenic contaminant source. Findings in most of the non-visibly oiled turtles were suggestive of low-level exposure to PAHs from a combination of petrogenic, pyrogenic and bio- 
genic sources. These values may represent background exposure to PAHs for sea turtles in the northern GoM unrelated to the DWH spill, but pre-spill samples were not available for comparison. Overall, the results of petroleum chemical analyses of both external oil samples and internal samples of sea turtles from the GOM during and after the DWH oil spill supported the findings of visual oiling observations.

Acknowledgements. We appreciate the timely chemical and data analyses provided by Daryle Boyd, Jennie Bolton, Jonelle Herman, Ron Pearce and Catherine Sloan at the National Marine Fisheries Service's NWFSC in Seattle, WA. Sea turtle sampling was possible due to the invaluable contributions of participants in the Sea Turtle Stranding and Salvage Network and the many dedicated individuals that rescued oiled turtles during response to the DWH oil spill. We greatly appreciate the logistical assistance of Danya McLamb of Industrial Economics and the guidance provided by Diane Wehner, Laurie Sullivan and Tom Brosnan from the National Ocean Service's Office of Response and Restoration. This study was part of the Deepwater Horizon NRDA being conducted cooperatively among NOAA, other Federal and State Trustees, and BP. All animal sampling was conducted under sanctioned oil spill response activities and rehabilitation permits provided by the National Marine Fisheries Service, United States Fish and Wildlife Service, and Florida Fish and Wildlife Conservation Commission. Postmortem animal sampling conducted at the University of Florida followed approved Institutional Animal Care and Use Committee protocols.

\section{LITERATURE CITED}

Alam SK, Brim MS (2000) Organochlorine, PCB, PAH, and metal concentrations in eggs of loggerhead sea turtles (Caretta caretta) from northwest Florida, USA. J Environ Sci Health B 35:705-724

Anastassiades M, Lehotay SJ, Stainbaher D, Schenck FJ (2003) Fast and easy multiresidue method employing acetonitrile extraction/partitioning and 'dispersive solidphase extraction' for the determination of pesticide residues in produce. J AOAC Int 86:412-431

Batchu SR, Ramirez CE, Gardinali PR (2014) Stability of dioctyl sulfosuccinate (DOSS) towards hydrolysis and photodegradation under simulated solar conditions. Sci Total Environ 481:260-265

* Bell B, Spotila JR, Congdon J (2006) High incidence of deformity in aquatic turtles in the John Heinz National Wildlife Refuge. Environ Pollut 142:457-465

Benner RA Jr., El Saida KR, Jester ELE, Flurer RA and others (2010) Investigation of Corexit® 9500 dispersant in Gulf of Mexico seafood species. US Food and Drug Administration, Washington, DC

Bruner KA, Fisher SW, Landrum PF (1994) The role of zebra mussel, Dreissena polymorpha, in contaminant cycling: I. The effect of body size and lipid content on the bioconcentration of PCBs and PAHs. J Gt Lakes Res 20:725-734

Bugoni L, Krause L, Petry MV (2001) Marine debris and human impacts on sea turtles in southern Brazil. Mar Pollut Bull 42:1330-1334

Camacho M, Boada LD, Orós J, Calabuig P, Zumbado M,
Luzardo OP (2012) Comparative study of polycyclic aromatic hydrocarbons (PAHs) in plasma of eastern Atlantic juvenile and adult nesting loggerhead sea turtles (Caretta caretta). Mar Pollut Bull 64:1974-1980

* Camacho M, Luzardo OP, Boada LD, López Jurado LF, Medina M, Zumbado M, Orós J (2013) Potential adverse health effects of persistent organic pollutants on sea turtles: evidences from a cross-sectional study on Cape Verde loggerhead sea turtles. Sci Total Environ 458-460: 283-289

Camacho M, Boada LD, Orós J, López P, Zumbado M, Almeida-González M, Luzardo OP (2014) Monitoring organic and inorganic pollutants in juvenile live sea turtles: results from a study of Chelonia mydas and Eretmochelys imbricata in Cape Verde. Sci Total Environ 481:303-310

* Campo P, Venosa AD, Suidan MT (2013) Biodegradability of Corexit 9500 and dispersed South Louisiana crude oil at 5 and $25^{\circ} \mathrm{C}$. Environ Sci Technol 47:1960-1967

Collier TK, Anulacion BF, Arkoosh MR, Dietrich JP and others (2014) Effects on fish of polycyclic aromatic hydrocarbon (PAH) and naphthenic acid exposures. In: KB Tierney, AP Farrell, CJ Brauner (eds) Organic chemical toxicology of fishes. Fish physiology, Vol 33. Academic Press, Amsterdam, p 195-255

da Silva DAM, Bicego MC (2010) Polycyclic aromatic hydrocarbons and petroleum biomarkers in São Sebastião Channel, Brazil: assessment of petroleum contamination. Mar Environ Res 69:277-286

da Silva DAM, Buzitis J, Krahn MM, Bícego MC, PiresVanin AMS (2006) Metabolites in bile of fish from São Sebastião Channel, São Paulo, Brazil as biomarkers of exposure to petrogenic polycyclic aromatic compounds. Mar Pollut Bull 52:175-183

* Drabeck DH, Chatfield MWH, Richards-Zawacki CL (2014) The status of Louisiana's diamondback terrapin (Malaclemys terrapin) populations in the wake of the Deepwater Horizon oil spill: insights from population genetic and contaminant analyses. J Herpetol 48:125-136

* DWH NRDA (Deepwater Horizon Natural Resource Damage Assessment) Trustees (2016) Deepwater Horizon oil spill: final programmatic damage assessment and restoration plan and final programmatic environmental impact statement. NOAA, Silver Spring, MD. http://www.gulf spillrestoration.noaa.gov/restoration-planning/gulf-plan/

Flurer RA, Boyd BL, Gamble B, Gratz S and others (2010) Determination of dioctylsulfosuccinate in select seafoods using a QuEChERS extraction with liquid chromatography-triple quadrupole mass spectrometry. US Food and Drug Administration, Washington, DC

Geraci JR, St. Aubin DJ (eds) (1990) Sea mammals and oil: confronting the risks. Academic Press, San Diego, CA

KGodrich MS, Melancon MJ, Davis RA, Lech JJ (1991) The toxicity, bioaccumulation, metabolism and elimination of dioctyl sodium sulfosuccinate DSS in rainbow trout (Oncorhynchus mykiss). Water Res 25:119-124

Gramentz D (1988) Involvement of loggerhead turtle with the plastic, metal and hydrocarbon pollution in the central Mediterranean. Mar Pollut Bull 19:11-13

* Hall RJ, Belisle AA, Sileo L (1983) Residues of petroleum hydrocarbons in tissues of sea turtles exposed to the Ixtox oil spill. J Wildl Dis 19:106-109

* Hart KM, Mooreside P, Crowder LB (2006) Interpreting the spatio-temporal patterns of sea turtle strandings: going with the flow. Biol Conserv 129:283-290 
Hatlen K, Sloan CA, Burrows DG, Coller TK, Scholz NL, Incardona JP (2010) Natural sunlight and residual fuel oils are an acutely lethal combination for fish. Aquat Toxicol 99:56-64

Hellou J, Leonard J (2004) Polycyclic aromatic hydrocarbon bioaccumulation and biotransformation products in trout exposed through food pellets. Polycycl Aromat Comp 24: $697-712$

*Hellou J, Leonard J, Anstey C (2002) Dietary exposure of finfish to aromatic contaminants and tissue distribution. Arch Environ Contam Toxicol 42:470-476

Holliday DK, Roosenburg WM, Elskus AA (2008) Spatial variation in polycyclic aromatic hydrocarbon concentrations in eggs of diamondback terrapins, Malaclemys terrapin, from the Patuxent River, Maryland. Bull Environ Contam Toxicol 80:119-122

*Houma ICP Aerial Dispersant Group (2010) Deepwater Horizon MC252 aerial dispersant response. After Action Report, Houma, LA. http://www.mdl2179trialdocs.com/ releases/release201501260800005/TREX-013037.pdf

Incardona JP, Vines CA, Anulacion BF, Baldwin DH and others (2012) Unexpectedly high mortality in Pacific herring embryos exposed to the 2007 Cosco Busan oil spill in San Francisco Bay. Proc Natl Acad Sci USA 109:E51-E58

* Incardona JP, Gardner LD, Linbo TL, Brown TL and others (2014) Deepwater Horizon crude oil impacts the developing hearts of large predatory pelagic fish. Proc Natl Acad Sci USA 111:E1510-E1518

Iqbal J, Gisclair D, McMillin DJ, Portier RJ (2007) Aspects of petrochemical pollution in southeastern Louisiana (USA): pre-Katrina background and source characterization. Environ Toxicol Chem 26:2001-2009

Johnson LL, Ylitalo GM, Myers MS, Anulacion BF, Buzitis J, Collier TK (2015) Aluminum smelter-derived polycyclic aromatic hydrocarbons and flatfish health in the Kitimat marine ecosystem, British Columbia, Canada. Sci Total Environ 512-513:227-239

Jonsson G, Bechmann RK, Bamber SD, Baussant T (2004) Bioconcentration, biotransformation, and elimination of polycyclic aromatic hydrocarbons in sheepshead minnows (Cyprinodon variegatus) exposed to contaminated seawater. Environ Toxicol Chem 23:1538-1548

Jung JH, Hicken CE, Boyd D, Anulacion BF, Carls MG, Shim WJ, Incardona JP (2013) Geologically distinct crude oils cause a common cardiotoxicity syndrome in developing zebrafish. Chemosphere 91:1146-1155

Krahn MM, Stein JE (1998) Assessing exposure of marine biota and habitats to petroleum compounds. Anal Chem 70:186A-192A

Krahn MM, Burrows DG, Ylitalo GM, Brown DB and others (1992) Mass spectrometric analysis for aromatic compounds in bile of fish sampled after the Exxon Valdez oil spill. Environ Sci Technol 26:116-126

Krahn MM, Ylitalo GM, Buzitis J, Chan S, Varanasi U (1993) Rapid high-performance liquid chromatographic methods that screen for aromatic compounds in environmental samples. J Chromatogr A 642:15-32

Kujawinski EB, Soule MCK, Valentine DL, Boysen AK, Longnecker K, Redmond MC (2011) Fate of dispersants associated with the Deepwater Horizon oil spill. Environ Sci Technol 45:1298-1306

Meador JP, Stein JE, Reichert WL, Varanasi U (1995) Bioaccumulation of polycyclic aromatic hydrocarbons by marine organisms. Rev Environ Contam Toxicol 143: 79-165
Meyer E, Eskew EA, Chibwe L, Schrlau J, Simonich SLM, Todd BD (2016) Organic contaminants in western pond turtles in remote habitat in California. Chemosphere 154: 326-334

Milton S, Lutz P, Shigenaka G (2003) Oil toxicity and impacts on sea turtles. In: Shigenaka G (ed) Oil and sea turtles: biology, planning, and response. NOAA, National Ocean Service, Office of Response and Restoration, Seattle, WA, p 35-47

Mitchelmore CL, Bishop C, Collier TK (2017) Toxicological estimation of mortality of oceanic sea turtles oiled during the Deepwater Horizon oil spill. Endang Species Res 33: $39-50$

*Mitra S, Lalicata JJ, Allison MA, Dellapenna TM (2009) The effects of Hurricanes Katrina and Rita on seabed polycyclic aromatic hydrocarbon dynamics in the Gulf of Mexico. Mar Pollut Bull 58:851-857

* Orós J, Torrent A, Calabuig P, Déniz S (2005) Diseases and causes of mortality among sea turtles stranded in the Canary Islands, Spain (1998-2001). Dis Aquat Org 63: 13-24

Overton EB, Ashton BM, Miles MS (2004) Historical polycyclic aromatic and petrogenic hydrocarbon loading in northern central Gulf of Mexico shelf sediments. Mar Pollut Bull 49:557-563

Parkinson A (2001) Biotransformation of xenobiotics. In: Klaassen CD (ed) Casarett \& Doull's toxicology: the basic science of poisons. McGraw-Hill, New York, NY, p 133-224

* Peterson CH, Rice SD, Short JW, Esler D, Bodkin JL, Ballachey BE, Irons DB (2003) Long-term ecosystem response to the Exxon Valdez oil spill. Science 302:2082-2086

Kamalhosa MJ, Paiga P, Morais S, Delerue-Matos C, Oliveira MBPP (2009) Analysis of polycyclic aromatic hydrocarbons in fish: evaluation of a quick, easy, cheap, effective, rugged and safe extraction method. J Sep Sci 32:3529-3538

Reddy CM, Arey JS, Seewald JS, Sylva SP and others (2012) Composition and fate of gas and oil released to the water column during the Deepwater Horizon oil spill. Proc Natl Acad Sci USA 109:20229-20234

Koubal WT, Collier TK, Malins DC (1977) Accumulation and metabolism of carbon-14 labeled benzene, naphthalene, and anthracene by young coho salmon (Oncorhynchus kisutch). Arch Environ Contam Toxicol 5:513-529

Rowe CL, Mitchelmore CL, Baker JE (2009) Lack of biological effects of water accommodated fractions of chemically- and physically-dispersed oil on molecular, physiological, and behavioral traits of juvenile snapping turtles following embryonic exposure. Sci Total Environ 407: 5344-5355

Sloan CA, Anulacion BF, Baugh KA, Bolton JL and others (2014) Northwest Fisheries Science Center's analyses of tissue, sediment, and water samples for organic contaminants by gas chromatography/mass spectrometry and analyses of tissue for lipid classes by thin layer chromatography/flame ionization detection. NOAA Technical Memorandum NMFS-NWFSC-125. US Department of Commerce, Seattle, WA

Stacy B (2012) Summary of findings for sea turtles documented by directed captures, stranding response, and incidental captures under response operations during the BP DWH MC252 oil spill. DWH sea turtles NRDA technical working group report. Prepared for NOAA Assessment and Restoration Division 
Stacy B (2015) Summary of necropsy findings for non-visibly oiled sea turtles documented by stranding response in Alabama, Louisiana, and Mississippi 2010 through 2014. DWH sea turtles NRDA technical working group report. Prepared for NOAA Assessment and Restoration Division

Troisi GM, Bexton S, Robinson I (2006) Polyaromatic hydrocarbon and PAH metabolite burdens in oiled common guillemots (Uria aalge) stranded on the east coast of England (2001-2002). Environ Sci Technol 40:7938-7943

Varanasi U, Gmur DJ (1981) Hydrocarbon and metabolites in English sole (Parophrys vetulus) exposed simultaneously to $\left[{ }^{3} \mathrm{H}\right]$ benzo(a)pyrene and $\left[{ }^{14} \mathrm{C}\right]$ naphthalene in oilcontaminated sediment. Aquat Toxicol 1:49-67

Varanasi U, Stein JE, Nishimoto M (1989) Biotransformation and disposition of polycyclic aromatic hydrocarbons (PAH) in fish. In: Varanasi U (ed) Metabolism of polycyclic aromatic hydrocarbons in the aquatic environment. CRC Press, Boca Raton, FL, p 93-149

Varanasi U, Brown DW, Hom T, Burrows DG and others (1993) Volume II: Supplemental information concerning a survey of Alaska subsistence fish, marine mammal, and invertebrate samples collected 1989-91 for exposure to oil spilled from the Exxon Valdez. NOAA Technical Memorandum NMFS-NWFSC-13. US Department of

Editorial responsibility: Andy Landry (Guest Editor), Galveston, Texas, USA
Commerce, Seattle, WA

*Venkatesan MI (1988) Occurrence and possible sources of perylene in marine sediments-a review. Mar Chem 25: $1-27$

Wang Z, Hollebone BP, Fingas M, Fieldhouse B and others (2003) Characteristics of spilled oils, fuels, and petroleum products: 1. Composition and properties of selected oils. EPA/600/R-03/072. US Environmental Protection Agency, Research Triangle Park, NC

Xu X, Zhang J, Zhang L, Liu W, Weisel CP (2004) Selective detection of monohydroxy metabolites of polycyclic aromatic hydrocarbons in urine using liquid chromatography/triple quadrupole tandem mass spectrometry. Rapid Commun Mass Spectrom 18:2299-2308

Yender RA, Mearns AJ (2003) Case studies of spills that threaten sea turtles. In: Shigenaka G (ed) Oil and sea turtles: biology, planning, and response. NOAA, National Ocean Service, Office of Response and Restoration, Seattle, WA, p 69-86

Ylitalo GM, Krahn MM, Dickhoff WW, Stein JE and others (2012) Federal seafood safety response to the Deepwater Horizon oil spill. Proc Natl Acad Sci USA 109: 20274-20279

Zar ZH (1999) Biostatistical analysis, 4th edn. Prentice Hall, Upper Saddle River, NJ

Submitted: Febrary 8, 2016; Accepted: August 16, 2016 Proofs received from author(s): October 7, 2016 